\title{
DETERMINAN STRATEGIC PARTNER SUMBER DAYA MANUSIA PADA PEGAWAI KANTOR PELAYANAN PAJAK PRATAMA MAGELANG
}

\author{
Kesi Risnawati \\ Lukluk Atul Hidayati \\ Universitas Muhammadiyah Magelang \\ e-mail: loekloek.a2@gmail.com
}

\begin{abstract}
ABSTRACK
This research aims to analyze whether the influence of knowledge management, strategic planning and organizational culture on strategic HR partner in Tax officer Pratama Magelang either simultaneously or partially. The method used was purposive sampling, with 50 respondents. The analytical tool used is multiple linier regression. The result shows that there is a significant effect simultaneously or jointly of knowledge management, strategic planning, and organizational culture on strategic partner. The effect of 59.9\% while the remaining 40,1\% is influenced by other variables that they are not examined. Strategic planning is a variable that has the most dominant influence on HR strategic partner.
\end{abstract}

Keywords: strategic planning, knowledge management, strategic planning, organizational culture

\section{PENDAHULUAN}

Sumber daya manusia menempati kedudukan strategis dan penting bagi perusahaan. Sumber daya manusia membuat sumber daya perusahaan lainnya bekerja. Dibutuhkan suatu pengelolaan sumber daya yang baik dan adil agar semua unsur perusahaan mampu bekerja dengan baik. Banyak hal dapat dilakukan untuk mengelola sumber daya manusia. Pengeloalaan sumber daya manusia dimulai sejak saat penarikan sampai pada masa pensiun. Manajemen harus mampu mendorong sumber daya manusia yang dimiliki agar memiliki kinerja baik dan memiliki keunggulan kompetitif. Kegiatan ini harus dilakukan secara terus menerus dan berkesinambungan. Penghargaan kinerja perlu dilakukan salah satunya adalah dengan selalu menilai prestasi kerja karyawan dan memberikan suatu penghargaan (reward) atas hasil yang dicapai tersebut.Penelitian yang telah dilakukan oleh universitas Michigan antara tahun 1988-1992 memperlihatkan bahwa organisasi-organisasi atau perusahaan-perusahaan telah menggeser fokus strateginya dalam bersaing menjadi lebih besar. Penelitian tersebut menunjukkan bahwa perubahan yang banyak dilakukan perusahaan ternyata berfokus pada bagian SDM.

Terjadi pergeseran paradigma, bahwa intangible asset lebih penting daripada sumber daya tangible dalam pengambilan keputusan strategik (Pehrsson, 2008: 25). Aset intangible, knowledge diakui secara luas sebagai aset organisasi paling penting untuk menciptakan value dan keunggulan kompetitif berkelanjutan (Sintaasih dan Surahman, 2011: 5). Knowledge organisasi terbukti berperan sebagai input kunci bagi proses perumusan strategi manufaktur, mengarahkan pengembangan kapabilitas menciptakan nilai produk (Paiva et at., 2008: 156). 
Penggunaan marketingknowledge perusahaan cabang berdampak positif pada pengembangan strategik Multi National Corporation (Hoim dan Sliarma, 2006: 4). Knowledge begitu strategis bagi organisasi, sehingga knowledge management telah dilakukan dengan sangat sukses oleh banyak organisasi terkemuka (Sintaasih dan Surahman, 2011: 3). Knowledge management merupakan serangkaian proses mengubah data dan informasi menjadi pengetahuan bermanfaat untuk berbagai kepentingan organisasi. Proses ini meliputi penciptaan, akuisisi, penyimpanan, berbagi, dan penggunaan pengetahuan. Bentuk dan kemampuan organisasi dalam mengelola pengetahuan (know-ledge management) sangat mempengaruhi kualitas pengetahuan yang dihasilkan dan pada akhirnya kualitas tindakan ataupun keputusan dan penggunaan knowledge tersebut. Beberapa kajian empiris telah membuktikan bahwa knowledge management berpengaruh signifikan pada kinerja organisasi, kinerja inovasi dan keunggulan kompetitif. Knowledgemanagement juga terbukti berpengaruh signifikan pada strategi pengembangan produk baru dan kinerja pengembangan produk baru (Sintaasih dan Surahman, 2011: 4).

Perencanaan strategik menurut Syamsudin (2007: 19) adalah perencanaan yang mengandung pendekatan strategicissues yang dihadapi dalam upaya membangun kinerja. Manajemen strategic merupakan rangkaian dua perkataan yang terdiri dan kata "manajemen" dan "strategis" yang masing- masing memiliki perkataan tersendiri, yang kemudian setelah di rangkaiakan menjadi pengertian sendiri pula. Sebagaimana dikemukakan Winardi (2000:9) "management is the proses of planning, organizing, leading, and controlling that encompasses human, material, financial and information resources in an organizational environment". Pendekatan strategik dalam konteks manajemen meliputi Tiga langkah utama: strategicplaning sebagai dokumen formal: strategic manajeman sebagai upaya untuk mengelola proses perubahan dan strategic thing/thing, sebagai kerangka dasar untuk menilai kebutuhan, merumuskan tujuan dan hasil yang ingin dicapai serta berkesinambungan.

Budaya organisasi merupakan sistem penyebaran kepercayaan dan nilai-nilai yang berkembang dalam suatu organisasi dan mengarahkan perilaku anggota-anggotanya. Budaya organisasi dapat menjadi instrumen keunggulan kompetitif yang utama, yaitu bila budaya organisasi mendukung strategi organisasi, dan bila budaya organisasi dapat menjawab atau mengatasi tantangan lingkungan dengan cepat dan tepat. Perilaku manajer yang memiliki standar tinggi merupakan salah satu indikator juga efektivitas manajemen, yang berarti bahwa budaya organisasi telah dikelola dengan baik. Beberapa literatur pemakaian istilah corporate culture biasa diganti dengan istilah organization culture. Kedua istilah ini memiliki pengertian yang sama. Karena itu dalam penelitian ini kedua istilah tersebut digunakan secara bersama-sama, dan keduanya memiliki satu pengertian yang sama. Beberapa definisi budaya organisasi dikemukakan oleh para ahli. Moeljono Djokosantoso (2003: 17 dan 18) menyatakan bahwa budaya korporat atau budaya manajemen atau juga dikenal dengan istilah budaya kerja merupakan nilai-nilai dominan yang disebarluaskan didalam organisasi dan diacu sebagai filosofi kerja karyawan.

Mengingat arti penting dan keterkaitan tiap faktor yang berhubungan dengan penerapan strategicpartner SDM, perlu adanya suatu upaya yang dilakukan untuk memantau faktor tersebut. Tujuannya adalah untuk meningkatkan dan mempertahankan kinerja yang akan dihasilkan melalui konsep yang akan dicapai. Atas dasar hal ini, maka judul yang diambil adalah "Pengaruh Knowledge Management, Perencanaan Strategik Dan Budaya Organisasi Terhadap Strategic Partner Sumber Daya Manusia" yang merupakan penelitian pada Pegawai Kantor Pelayanan Pajak Pratama Magelang. 


\section{REVIEW LITERATUR DAN HIPOTESIS}

Kunci meningkatkan kinerja organisasi adalah dengan memastikan aktivitas SDM mendukung usaha organisasi yang terfokus pada produktivitas, pelayanan dan kualitas. Untuk mencapai sasaran tersebut, manajemen SDM haruslah terdiri dan aktivitas-aktivitas yang saling berkaitan. Aktivitas SDM tersebut adalah sebagai berikut (Siagian, 2007: 11):

1) Perencanaan dan analisis SDM, aktivitas perencanaan dilakukan untuk mengantisipasi kekuatan yang akan mempengaruhi pasokan dan permintaan akan tenaga kerja. Sedangkan, analisis dan penilaian selektivitas SDM juga penting dilakukan sebagai bagian dan menjaga daya saing organisasi.

2) Kesetaraan Kesempatan Bekerja, kepatuhan pada hukum dan peraturan Kesetaraan Kesempatan Bekerja (Equal Employment Opportunity - EEO) mempengaruhi aktifitas SDM lainnya dan menjadi bagian yang tidak terpisahkan dan manajemen SDM. Contohnya, perencanaan SDM harus memastikan sumber tenaga kerja yang bervariasi untuk memenuhi jumlah tenaga kerja yang ditetapkan oleh hukum dan peraturan. Selain itu, pada saat perekrutan, seleksi dan pelatihan, semua manajer harus mengerti peraturan ini.

3) Perekrutan Staffing, sasaran perekrutan menyediakan pasokan tenaga kerja yang cukup untuk memenuhi kebutuhan organisasi. Uraian pekerjaan (job description) dan spesifikasi pekerjaan (job spesification), dapat dipersiapkan untuk proses perekrutan. Proses seleksi menekankan pada pemilihan orang yang memenuhi kriteria persyaratan (qualified) untuk mengisi lowongan pekerjaan.

4) Pengembangan SDM, diperlukan pelatihan yang berkesinambungan untuk tanggap pada perubahan teknologi. Pengembangan semua tenaga kerja, termasuk pengawas (supervisor) dan manajer, diperlukan untuk menyiapkan organisasi menghadap tantangan ke depan. Perencanaan Karir (Career Planning) mengidentifikasi jalur dan aktivitas setiap individu yang berkembang di suatu organisasi.

5) Kompensasi dan Keuntungan, kompensasi diberikan pada tenaga kerja yang melakukan kerja organisasi seperti pembayaran (pay), insentif(incentive), dan keuntungan (benefits). Perusahaan harus mengembangkan dan selalu memperbaiki sistem upah dan gaji. Program insentif seperti pembagian keuntungan dan penghargaan atas produktivitas semakin banyak dilakukan.

Dibutuhkan sumberdaya manusia yang berkemampuan baik (perform) sehingga dapat berperan dalam tuntutan terhadap peran mereka yang semakin kompleks. Peran-peran tersebut menempatkan SDM sebagai aktor kritikal dalam meningkatkan keefektifan dan kemampuan organisasi untuk dapat berkompetisi. Penelitian yang dilakukan Conner dan Ulrich (2006 :3) melaporkan penyelidikan empiris berbagai peran profesional sumberdaya manusia dan menjelaskan implikasi bagi pengembangan profesional sumberdaya manusia tersebut.

a. Strategic Partner SDM

Menurut Fatwan (2006: 28) strategic partner disebut hubungan kerja atau hubungan manusia atau disebut Industrial Peace yaotu hubungan antara pimpinan dengan para karyawan diperusahaan. Hubungan yang serasi dan harmonis antara majikan dan pekerja yang terdapat dalam organisasi usaha itu mutlak harus ditumbuhkan dan dipelihara demi kepentingan semua pihak Ketidakberhasilan memelihara hubungan yang harmonis akan berakibat terjadinya kerugian bagi banyak pihak, terutama bagi pihak majikan dan pekerja-pekerja yang bersangkutan.Hubungan itu biasanya dilakukan secara tertulis ataupun lisan asalkan 
kedua belah pihak secara jujur melaksanakan kewajiban dan hak masing-masing selaku mitra kerja.

b. Knowledge Management

Menurut Anshori (2004: 69) knowledge management merupakan pengetahuan yang dimiliki karyawan dalam mengenal sistem kerja yang ada dalam perusahaan dan karyawan mampu mengembangkan sistem yang ada. Setiap karyawan mempunyai peran di dalam meningkatkan perusahaannya. Sedangkan menurut Fatwan (2006: 76), knowledge management merupakan pengetahuan yang dimiliki karyawan dalam mengembangkan sistem kerja yang lebih efisien dalam pencapaian kinerja karyawan.

Menyadari adanya fenomena tersebut maka perusahaan melakukan suatu gebrakan dengan menerapkan knowledge management (KM) pada karyawannya. Berdasarkan penuturan Anshori (2004 :70) selaku General Manager SPH, knowledge management yang diterapkan pada perusahaan terbagi menjadi 2 yaitu, tacit knowledge dan explicit knowledge. Yang pertama adalah pengetahuan individu yang didapat dari pengalaman keseharian, yang sulit diduplikasikan dan diajarkan kepada orang lain dimana penulis mengkategorikan dalam bentuk pengetahuan individu atau personal knowledge. Yang kedua, pengetahuan yang bisa ditransformasikan antar individu sehingga lebih mudah dideskripsikan ke dalam dokumen, praktik, pelatihan dan lainlain dimana penulis mengkategorikan dalam bentuk job procedure, dan technology.

Konsep Knowledge Management menjadi guidance tentang pengelolaan intangible assets yang menjadi pilar perusahaan dalam menciptakan nilai (dari produk/jasa/ solusi) yang ditawarkan perusahaan kepada pelanggannya. Oleh karena itu, pemahaman mengenai nilai buku perusahaan harus disertai dengan pemahaman nilai intangibleassets perusahaan. Jenis penerapan knowledgemanagement ada dua, yaitu:

1) Tacit Knowledge

Pada dasarnya tacit knowledge bersifat personal, dikembangkan melalui pengalaman yang sulit untuk diformulasikan dan dikomunikasikan (Carrillo et al., 2004: 43). Berdasarkan pengertiannya, maka tacit knowledge dikategorikan sebagai personal knowledge atau dengan kata lain pengetahuan yang diperoleh dari individu (perorangan). Menurut Bahm (1995, p.199) penelitian pada sifat dasar pengetahuan seketika mempertemukan perbedaan antara knower dan known, atau seringkali diartikan dalam istilah subject dan object, atau ingredient subjective dan objective dalam pengalaman.

Pengalaman yang diperoleh tiap karyawan tentunya berbeda-beda berdasarkan situasi dan kondisi yang tidak dapat diprediksi. Definisi experience yang diambil dari kamus bahasa Inggris adalah the process of gaining knowledge or skill over a period of time through seeing and doing things rather than through studying. Yang artinya proses memperoleh pengetahuan atau kemampuan selama periode tertentu dengan melihat dan melakukan hal-hal daripada dengan belajar.

2) Explicit knowledge

Explicit knowledge bersifat formal dan sistematis yang mudah untuk dikomunikasikan dan dibagi (Carrillo et al., 2004: 45). Penerapan explicit knowledge ini lebih mudah karena pengetahuan yang diperoleh dalam bentuk tulisan atau pernyataan yang didokumentasikan, sehingga setiap karyawan dapat mempelajarinya secara independent. Explicit knowledge dalam penelitian ini adalah job procedure dan technology. Job procedure adalah tanggung jawab atau tugas yang bersifat formal atau perintah resmi atau cara melakukan hal-hal. Berdasarkan pernyataan Anshori selaku pihak yang 
mencetuskan knowledgemanagement, salah satu bentuk konkret dari explicit knowledge adalah Standard Operation Procedure.

Standard Operation Procedure atau prosedur pelaksanaan dasar dibuat untuk mempertahankan kualitas dan hasil kerja, dimana tugas-tugas akan semakin mudah dikerjakan dan tamu akan terbiasa dengan sistem pelayanan yang ada.

Teknologi merupakan salah satu elemen pokok yang terdapat pada knowledge management, dikenal sebagai media yang mempermudah penyebaran explicit knowledge. Salah satu teknologi paling mutakhir yang saat ini digunakan oleh banyak perusahaan untuk proses penyebaran knowledge adalah internet, dimana hal ini didasarkan pada kebutuhan untuk mengakses knowledge dan melakukan kolaborasi, komunikasi serta sharing knowledge secara "on line".

Setelah era efisiensi pada tahun 1950an dan 1960an, era kualitas pada tahun 1970an dan 1980an,serta fleksibilitas dalam tahun 1980an dan 1990an, maka kini hidup dalam era inovasi (Janszen, 2000: 34). Era inovasi ini muncul karena situasi bisnis saat ini dipengaruhi oleh banyak sekali perubahan yang berjalan cepat dan sulit diramalkan, perubahan perubahan tersebut terutama disebabkan oleh pesatnya perkembangan teknologi informasi, terjadinya globalisasi, serta demokratisasi (Business Week, 2001: Garvin, 2000; Schiro 2000: 15). Di sektor pemerintah, tuntutan terhadap pelayanan publik dan transparansi menjadi suatu hal yang tak dapat dihindari (Schiro, 2000: 16), oleh sebab itu organisasi harus terus menerus mencari cara untuk menciptakan dan mewujudkan nilai (value) melalui inovasi (Janszen, 2000; Yoffie, 1997: 15).

Istilah inovasi telah didefinisikan oleh Josepth Schumpeter sebagai komersialisasi semua kombinasi yang didasari oleh pemanfaatan (1) bahan dan komponen baru, (2) proses baru, (3) pasar baru, dan (4) bentuk organisasi baru (Janszen, 2000: 17). Dengan kata lain, menurut definisi ini, inovasi merupakan komposit dan kedua bidang, yaitu bidang teknis dan bidang bisnis. Bila hanya melibatkan teknologi, maka Schumpeter menamakannya invensi (invention), begitu bidang bisnis dilibatkan, maka muncul inovasi (innovation).

Berbagai rujukan mendukung adanya indikasi bahwa inovasi menjadi indikator adanya proses penciptaaan pengetahuan baru di organisasi. Nonaka dan Takeuchi (2005: 21) mengemukakan bahwa penciptaan pengetahuan merupakan esensi dan inovasi: "organizational knowledge creation is the key to the distinctive ways of Japanese companies innovate. They are especially good at bringing about innovation continuously, incrementally, and spirally ".

Proses penciptaaan pengetahuan dalam era inovasi, adalah kemampuan organisasi untuk menciptakan pengetahuan merupakan hal yang sangat mendasar, namun diketahui bahwa penciptaaan pengetahuan terjadi dalam benak individu-individu (manusia) yang berada di organisasi. Tanpa individu-individu tersebut, organisasi tak mampu menciptakan pengetahuan yang dibutuhkannya untuk melakukan berbagai inovasi (dalam berbagai penelitian konseptual maupun empiris).

Proses penciptaaan pengetahuan yang mulai dan akses informasi dan pengalaman, refleksi individu-individu atas tindakan di masa lalu, kemampuan menyerap pengetahuan, motivasi individu untuk belajar persepsi atas kepenilaian aktivitas yang menuju terciptanya pengetahuan baru tersebut. Persoalan lain,adalah bagaimana mengelola pengetahuan yang cukup rumit dan kompleks, serta dalam gejolak lingkungan dan semakin cepatnya siklus kejadian atau peristiwa bukan merupakan pekerjaan yang mudah dan penuh 
dengan berbagai tantangan dan hambatan dalam upaya mengelola pengetahuan menjadi pengetahuan baru.

Di organisasi-organisasi modern saat ini, pandangan tentang manajemen perubahan ini bersinggungan pula dengan cara mereka memberlakukan pengetahuan sebagai modal intelektual. Manajemen perubahan mencakup pninsip, alat analisis, teknologi informasi, teori perubahan strategis, pengingkatan fungsi individu, sistem, struktur dan proses kerja yang didahului dengan disain organisasi, perbaikan kinerja pegawai, hubungan antar kelompok/bagian dalam suatu organisasi (Siagian, 2007).

\section{c. Perencanaan Strategik}

Perencanaan strategis (strategic plan) baru bisa memberikan jalur migrasi (migration path) yang bisa mengatasi kelemahankelemahan yang ada, mengeksploitasi kekuatan dan memunculkan kebutuhan-kebutuhan baru. Strategi, didefinisikan dalam buku ini, adalah "serangkaian aksi yang terintegrasi dan diarahkan untuk meningkatkan kesejahteraan dan kekuatan perusahaan dalam jangka panjang" (Hasibuan, 2006: 21). Oleh sebab itu, rencana (plan) harus terintegrasi tidak hanya dalam hal informasi, sistem dan teknologi melalui kegiatan yang koheren, akan tetapi juga dalam hal perkembangan kebutuhan bisnis. "jangka panjang" menandakan ketidakpastian., baik dalam kebutuhan bisnis dan potensi keuntungan yang bisa ditawarkan oleh beragam aplikasi dan teknologi (Hasibuan, 2006: 23). Satu-satunya hal yang pasti adalah perubahan. Perubahan keadaan menandakan bahwa organisasi harus mampu memberikan respons terhadap masalah dan oportuniti yang tidak terduga. Oleh sebab itu, pendekatan strategis jangan sampai memberikan rencana yang kaku, tapi dia harusnya menjadi sebuah lingkungan sistem informasi bisnis yang bisa beradaptasi begitu ada perubahan dalam lingkungan (environment).

Sistem Informasi dapat mengubah cara berkompetisi dalam bisnis. Membangun strategi Sistem Informasi (SI) atau Teknologi Informasi (TI) dimaksudkan sebagai berpikir strategis dan merencanakan manajemen jangka panjang yang efektif serta pengaruh optimal informasi dalam segala bentuk (Teguh. dkk. 2003: 4). Sistem Informasi dan Teknologi Informasi dengan menggunakan sarana manual dan sistem komputer, teknologi komputer, dan telekomunikasi. Termasuk di dalamnya aspek organisasi dan manajemen Sistem Informasi atau Teknologi Informasi. Peran strategis sistem informasi mencakup penggunaan teknologi informasi untuk menghasilkan produk, layanan dan kemampuan yang dapat memberi keunggulan strategis dalam berkompetisi menghadapi pasar global.

Strategi SI membawa bersama tujuan bisnis perusahaan, pemahaman mengenai informasi yang diperlukan untuk mendukung tercapainya tujuan, dan implementasi sistem komputer untuk menyediakan informasi yang dimaksud. Strategi SIJTI merupakan rencana untuk membangun sistem menuju visi masa depan dan peran SI dalam organisasi.

d. Budaya Organisasi

Budaya organisasi adalah pola asumsi dasar yang ditemukan atau dikembangkan oleh suatu kelompok orang selagi mereka belajar menyelesaikan masalah-masalah, menyesuaikan diri dengan lingkungan ekstemal, dan berintegrasi dengan lingkungan internal (Wirawan, 2007: 5). Dalam beberapa literatur pemakaian istilah corporate culture biasa diganti dengan istilah organizationculture. Kedua istilah ini memiliki pengertian yang sama. Karena itu dalam penelitian ini kedua istilah tersebut digunakan secara bersamasama, dan keduanya memiliki satu pengertian yang sama. 
Beberapa definisi budaya organisasi (dalam Soedjono, 2005: 3) dikemukakan oleh para ahli. Moeljono Djokosantoso (2003: 17 dan 18) menyatakan bahwa budaya korporat atau budaya manajemen atau juga dikenal dengan istilah budaya kerja merupakan nilai-nilai dominan yang disebar luaskan didalam organisasi dan diacu sebagai filosofi kerja karyawan. Susanto $(2007$; 3) memberikan definisi budaya organisasi sebagai nilai-nilai yang menjadi pedoman sumber daya manusia untuk teknik dan proses yang digunakan untuk meraih hasil tersebut; (4) Berorientasikepada manusia(Peopleorientation), adalah sejauh mana keputusan manajemen memperhitungkan efek hasil-hasil pada orangorang di dalam organisasi; (5) Berorientasi tim (Team orientation), adalah sejauh mana kegiatan kerja diorganisasikan sekitar tim-tim tidak hanya pada individu untuk mendukung kerjasama; (6) Agresifitas (Aggressiveness), adalah sejauh mana orang-orang dalam organisasi itu agresif dan kompetitif untuk menjalankan budaya organisasi sebaik-baiknya; (7) Stabilitas (Stability), adalah sejauh mana kegiatan organisasi menekankan status quo sebagai kontras dan pertumbuhan.

\section{Hipotesis}

Hipotesis adalah jawaban yang bersifat sementara dan membutuhkan pembuktian lebih lanjut secara empiris dan ilmiah (Djarwanto, 2001:20). Berkaitan dengan penelitian yang dilakukan saat ini, hipotesis yang diajukan adalah sebagai berikut :

$\mathrm{H}_{1} \quad$ : Terdapat pengaruh variabel knowledgemanagement, perencanaan strategik dan budaya organisasi terhadap penerapan strategicpartner SDM baik secara simultan maupun secara parsial.

$\mathrm{H}_{2}$ : Variabel perencanaan strategik berpengaruh paling dominan terhadap penerapan strategicpartner SDM.

\section{METODE PENELITIAN}

\section{Metode Pengumpulan Data}

Teknik pengumpulan dataprimer dengan menggunakan kuesioner yaitu cara melakukan pengumpulan data yang disajikan dalam bentuk pertanyaan-pertanyaan kepada responden terkait dengan pelayanan yang diterima sehingga responden dapat memberikan jawaban atas pertanyaan secara tertulis. Metode pengambilan sampel yang digunakan adalah metode purposive sampling.

\section{Definisi Operasional Variabel}

Definisi operasional variabel disusun untuk memberikan persepsi yang sama terhadap variabel-variabel yang diteliti melalui penjabaran indikator variabel tersebut. Berkaitab dengan penelitian ini, definisi operasional variabel yang ada adalah:

a. Knowledge Manajemen adalah kemampuan Kantor Pajak Pratama untuk menciptakan pengetahuan terhadap karyawan hal-hal yang sangat mendasar tentang pekerjaan yang dilakukan karyawan, sehingga penciptaaan pengetahuan dalam benak individu-individu (manusia) yang berada di Kantor Pajak Pratama Magelang.. Indikator-indikator untuk mengukur knowledgemanajemen yaitu: pengetahuan yang dimiliki setiap individu karyawan, karyawan mudah beradaptasi dengan alat-alat baru,karyawan bekerjasama dengan manajemen dalam menyelesaikan pekerjaan,karyawan bekerja sesuai dengan bidang ilmu yang dimiliki (profesionalisme) dan lingkungan menciptakan hubungan kerja yang memungkinkan pertukaran pengetahuan dan ketrampilan.

b. PerencanaanStrategikmerupakan serangkaian aksi yang terintegrasi dan diarahkan untuk meningkatkan kesejahteraan dan kekuatan di Kantor Pajak Pratama Magelang dalam jangka panjang, dengan menggunakan 
sistem dan teknologi melalui kegiatan yang koheren, untuk mendukung perkembangan di Kantor Pajak Pratama Magelang dimasa yang akan datang. Perencanaan strategik dalam penelitian ini diukur dengan menggunakan indikator sebagai berikut :penggunaan informasi yang didapat dari semua bagian untuk perencanaan strategi, sistem informasi yang dimiliki oleh perusahaan, kemampuan karyawan dalam penggunaan teknologi, perusahaan melibatkan karyawan dalam perencanaan dan perencanaan yang dibuat dapat terlaksana.

c. Budaya Organisasi merupakan belajar untuk menyelesaikan masalah-masalah, menyesuaikan diri dengan lingkungan ekstemal, dan berintegrasi dengan lingkungan internal di Kantor Pajak Pratama Magelang. Budaya organisasi dalam penelitian ini diukur dengan menggunakan indikatro sebagai berikut :karyawan konsisten dalam bekerja, manajemen memiliki standar kerja, manajemen mampu menyelesaikan masalah yang ada, komunikasi yang terjalin dalam lingkungan kerja dan manajemen mengembangkan kemampuan SDM karyawannya.

d. Strategic Partner adalah hubungan antara pimpinan dengan para karyawan di Kantor Pajak Pratama Magelang, yaitu hubungan kerja atau hubungan manusia, pemeliharaan hubungan dalam rangka keseluruhan proses manajemen sumber daya manusia berkisar pada pemikiran bahwa hubungan yang serasi dan harmonis antara majikan dan pekerja. Strategic patner dalam penelitian ini diukur dengan menggunakan indikator sebagai berikut :hubungan pihak manajemen dengan para pekerja, komunikasi pihak manajemen dengan para pekerja, pihak manajemen memberikan training kepada karyawan, bentuk pengambilan keputusan pihak manajemen dipertimbangkan dengan karyawan dan Pihak manajemen memberikan sosialisasi tentang alat dan teknologi baru.

\section{Metode Analisis Data}

Analisis liniear berganda digunakan untuk mengetahui mengetahui pengaruh tangible, reliability, responsiveness, assurance dan Emphaty terhadap Kepuasan Konsumen, dengan rumus penulisan regresinya; $Y=a+b_{1} X_{1}+b_{2} X_{2}$ $+\mathrm{b}_{3} \mathrm{X}_{3}+\mathrm{e}$, dimana;

$\mathrm{Y}=$ strategic partner

a. = Constant Value

$\mathrm{X}_{1}=$ knowledge management

$\mathrm{X}_{2}=$ perencanaan strategik

$\mathrm{X}_{3}=$ budaya organisasi

$\mathrm{b}_{1}=$ Koefisien Regresi Variabel knowledge management

$\mathrm{b}_{2}=$ Koefisien Regresi Variabel perencanaan strategik

$\mathrm{b}_{3}=$ Koefisien Regresi Variabel budaya organisasi

$\mathrm{e}=$ error term

PEMBAHASAN DAN HASIL

\section{Uji Validitas}

Tabel 1

Uji Validitas

\begin{tabular}{llll}
\hline Variabel & Pernyataan & R hitung & Kesimpulan \\
\hline & 1 & 0,637 & Valid \\
Knowledge & 2 & 0,696 & Valid \\
Management & 3 & 0,676 & Valid \\
& 5 & 0,721 & Valid \\
& 6 & 0,608 & Valid \\
Perencanaan & 7 & 0,862 & Valid \\
Strategik & 8 & 0,826 & Valid \\
& 9 & 0,693 & Valid \\
& 10 & 0,822 & Valid \\
Budaya & 11 & 0,842 & Valid \\
Organisasi & 13 & 0,822 & Valid \\
& 14 & 0,805 & Valid \\
& 15 & 0,602 & Valid \\
Strategic & 16 & 0,789 & Valid \\
Partner & 17 & 0,824 & Valid \\
& 18 & 0,812 & Valid \\
\hline Sumber: & 19 & 0,823 & Valid \\
& 20 & 0,745 & Valid \\
& (1) & 0,831 & Valid \\
\hline
\end{tabular}

Sumber: hasil olah data 
Berdasarkan jumlah n sampel sebanyak 50 responden diperoleh nilai $\mathrm{r}$ tabel pada $\mathrm{df}=48$ (n -2) sebesar 0,279 Berdasarkan tabel diatas dapat dilihat bahwa variabel knowledge management yang memiliki 5 item pernyataan menunjukkan bahwa semua item pernyataan memiliki nilai $\mathrm{r}$ hitung $>\mathrm{r}$ tabel dengan tingkat signifikansi dibawah 0,05 sehingga tiap item pertanyaan dapat dinyatakan valid dan dapat dilakukan pengujian lebih lanjut. Variabel perencanaan strategik yang memiliki 5 item pernyataan menunjukkan bahwa semua item pernyataan memiliki nilai $r$ hitung $>$ $r$ tabel dengan tingkat signifikansi dibawah 0,05 sehingga tiap item pertanyaan dapat dinyatakan valid dan dapat dilakukan pengujian lebih lanjut. Variabel budaya organisasi yang memiliki 5 item pernyataan menunjukkan bahwa semua item pernyataan memiliki nilai $r$ hitung $>r$ tabel dengan tingkat signifikansi dibawah 0,05 sehingga tiap item pertanyaan dapat dinyatakan valid dan dapat dilakukan pengujian lebih lanjut. Variabel strategicpartner yang memiliki 5 item pernyataan menunjukkan bahwa semua item pernyataan memiliki nilai $r$ hitung $>r$ tabel dengan tingkat signifikansi dibawah 0,05 sehingga tiap item pertanyaan dapat dinyatakan valid dan dapat dilakukan pengujian lebih lanjut.

\section{Uji Reliabilitas}

Tabel 2

Uji Reliabilitas

\begin{tabular}{lcc}
\hline \multicolumn{1}{c}{ Variabel } & $\begin{array}{c}\text { Cronbach's } \\
\text { Alpha }\end{array}$ & Kesimpulan \\
\hline Knowledge Management & 0,764 & Reliabel \\
Perencanaan Strategik & 0,807 & Reliabel \\
Budaya Organisasi & 0,797 & Reliabel \\
Strategic Partner & 0,809 & Reliabel \\
\hline
\end{tabular}

Sumber: hasil olah data

Dari tabel diatas dapat diketahui bahwa, semua nilai Cronbach alpha variabel yang diteliti memiliki nilai $>0,60$ atau berada diatas nilai Nunnaly $(0,60)$. Atas dasar hal tersebut, dapat dikatakan bahwa data-data pada tiap-tiap variabel, yaitu tangibles, reliability, responsiveness, assurance dan emphaty serta kepuasan konsumen memiliki tingkat kehandalan yang baik (reliable) sehingga dapat dilakukan analisis lebih lanjut.

\section{Analisis Data}

a. Regresi Liniear Berganda Berdasarkan hasil perhitungan diperoleh nilai persamaan regresi sebagai berikut; $\mathrm{Y}=9,138$ $+0,327 \mathrm{X} 1+0,432 \mathrm{X} 2+0,493 \mathrm{X} 3$, yang diinterpretasikan sebagai berikut ini:

(a) Nilai konstantasebesar 9,138 merupakan nilai strategic partner apabila variabel lain yang diteliti bernilai nol. Artinya, apabila variabel yang diteliti bernilai nol, maka strategicpartner akan tetap memiliki nilai (konstan/tetap). Hal ini disebabkan beberapa aspek yang berkaitan dengan strategic partner berupa ; pihak manajemen mempunyai hubungan yang baik dengan para karyawan, terjalin komunikasi antara manajemen degan karyawan, pihak manajemen memberikan training kepada karyawan, pengambilan keputusan pihak manajemen dipertimbangkan dengan para karyawan dan ada upaya dari manajemen untuk sosialisasi tentang teknologi baru.

$\left(b_{1}\right) \quad$ Nilai koefisien regresi variabel knowledgemanagement (X1) sebesar 0,327 merupakan perubahan nilai strategicpartner apabila variabel lain bernilai nol. Artinya adalah, strategicpartner dipersepsikan akan meningkat bila knowledgemanagement juga meningkat. Peningkatan ini terjadi karena aspek- aspek yang ada berupa ; karyawan yang memiliki pengetahuan dalam menyelesaikan pekerjaan, karyawan mudah beradaptasi dengan peralatan baru di perusahaan, karyawan bekerjasama dengan manajemen dalam menyelesaikan pekerjaan, karyawan bekerja sesuai dengan bidang ilmu yang dimiliki dan lingkungan yang dapat menciptakan hubungan kerja yang 
memungkinkan pertukaran pengetahuan dan ketrampilan.

$\left(b_{2}\right) \quad$ Nilai koefisien regresi variabel perencanaan strategik (X2) sebesar 0,432 merupakan kontribusi yang dapat diberikan oleh variabel perencanaan strategik terhadap variabel strategicpartner apabila variabel lain bernilai nol. Artinya adalah, strategicpartner akan meningkat bila perencanaan strategik juga meningkat. Peningkatan ini terjadi karena aspek- aspek yang ada pada perencanaan strategik berupa; penggunaan informasi yng didapat dari semua bagian untuk perencanaan strategik, system informasi yang dimiliki oleh perusahaan sudah baik, karyawan mampu dalam penggunaan teknologi, perusahaan melibatkan karyawan dalam perencanaan dan perencanaan yang dibuat dapat terlaksana.

$\left(b_{3}\right)$ Nilai koefisien regresi variabel budaya organisasi (X3) sebesar 0,493 merupakan kontribusi yang dapat diberikan oleh variabel budaya organisasi terhadap variabel strategic partner apabila variabel lain bernilai nol. Artinya adalah, strategic partner akan meningkat bila budaya organisasi juga meningkat. Peningkatan ini terjadi karena aspek- aspek yang ada pada budaya organisasi berupa; karyawan yang konsisten dalam bekerja, manajemen memiliki standar kerja, manajemen mampu menyelesaikan masalah yang ada, lingkungan kerja yang dapat menciptakan hubungan kerja yang komunikatif dan manajemen mampu mengembangkan SDM karyawannya.

b. Uji Hipotesis

1) Uji Koefisien Determinasi $\left(R^{2}\right)$

Berdasarkan hasil perhitungan analisis regresi linear berganda diperoleh Adjusted $R^{2}$ sebesar 0,599. Hasil tersebut menunjukkan bahwa kemampuan variabel knowledge management, perencanaan strategik dan budaya organisasi dalam menjelaskan perubahan strategic partner cukup kuat, yaitu sebesar 59,9 $\%$, sedangkan sisanya sebesar 40,1\% dipengaruhi oleh variabel lain yang tidak diteliti seperti motivasi, kepemimpinan dan kompensasi.

2) Uji F (Simultan)

Hasil analisis regresi linear berganda diperoleh nilai $\mathrm{F}$ hitung sebesar 25,397. Pada $\mathrm{df}_{1}=3$ dan $\mathrm{df}_{2}=46$ diperoleh nilai F tabel sebesar 2,807. Berdasarkan hasil perbandingan dapat diketahui bahwa $\mathrm{F}$ hitung 25,397 > F tabel 2,807, maka $\mathrm{H}_{0}$ ditolak, sehingga dapat dinyatakan bahwa knowledge management, perencanaan strategikdanbudaya organisasi berpengaruh secara simultan terhadap strategic partner. Hal ini membuktikan bahwa hipotesis yang diajukan terbukti kebenarannya.

3) Uji t (Parsial)

Pada tingkat signifikansi 0,05 (uji dua sisi) dengan $\mathrm{df}=44$ diperoleh nilai $\mathrm{t}$ tabel sebesar 2,015. Berdasarkan hasil koefisien regresi dapat dianalisis sebagai berikut:

a) Pengaruh knowledge management terhadap strategic partner

Diketahui nilai $\mathrm{t}$ hitung variabel $\mathrm{X}_{1}$, knowledge management sebesar 2,217. Berdasarkanhasil perbandingan menunjukkan bahwa nilai $\mathrm{t}$ hitung 2,217> t tabel 2,013, maka $\mathrm{H}_{0}$ ditolak, sehingga dapat dinyatakan bahwa knowledge management berpengaruh terhadap strategic partner.

b) Pengaruh perencanaan strategic terhadap strategic partner

Diketahui nilai t hitung variabel $\mathrm{X}_{2}$ perencanaan strategik sebesar 3,224. Berdasarkan hasil perbandingan menunjukkan bahwa nilai $\mathrm{t}$ hitung 3,224 > t tabel 2,013, maka $\mathrm{H}_{0}$ ditolak, sehingga dapat dinyatakan bahwa 
perencanaan strategik berpengaruh terhadap strategic partner.

c) Pengaruh budayaorganisasi terhadap strategic partner

Diketahui nilai $\mathrm{t}$ hitung variabel $\mathrm{X}_{3}$, budaya organisasi sebesar 3,017. Berdasarkan hasil perbandingan menunjukkan bahwa nilai t hitung 3,017 $>\mathrm{t}$ tabel 2,013, maka $\mathrm{H}_{0}$ ditolak, sehingga dapat dinyatakan bahwa budaya organisasi berpengaruh terhadap strategic partner.

4) Analisis Variabel Dominan

Berdasarkan hasil analisis yang ada dapat diketahui bahwa standardized coefficient variable perencanaan strategik memiliki nilai paling besar, yaitu 0,498 dengan nilai $P$ value paling signifikan yaitu 0,002 yang merupakan nilai tertinggi dari semua variabel bebas. Atas dasar hasil ini dapat dikatakan bahwa, variable perencanaan strategik merupakan variabel yang memiliki pengaruh paling dominan terhadap penerapan strategicpartner SDM.

\section{KESIMPULAN DAN SARAN}

Kesimpulan

Hasil analisis menunjukkan bahwa, berdasarkan uji $\mathrm{F}$ terdapat pengaruh yang signifikan secara simultan atau bersamasama dari variabel bebas yang terdiri dari knowledgemanagement, perencanaan strategik dan budaya organisasi terhadap variabel terikat yaitu strategic partner. Nilai Adjusted $R$ square sebesar 0,599 yang berarti variabel bebas yaitu, knowledge management, perencanaan strategik dan budaya organisasi berpengaruh terhadap variabel terikat, yaitu strategic partner sebesar $59,9 \%$ sedangkan sisanya $40,1 \%$ dipengaruhi oleh variabel lain yang tidak diteliti.Berdasarkan uji $\mathrm{t}$ terdapat pengaruh secara variabel bebas terhadap variabel terikat.
Variabel perencanaan strategik merupakan variabel yang memiliki pengaruh paling dominan terhadap penerapan strategic partner SDM. Hal ini didasarkan pada nilai standardized coefficient variabel perencanaan strategik memiliki nilai paling besar, yaitu 0,498 dengan nilai $p$ value paling signifikan yaitu 0,002 .

\section{Saran}

a. Pihak Kantor Pajak Pratama Magelang hendaknya meningkatkan komitmen untuk meningkatkan penerapan strategic partner, caranya adalah; pihak manajemen mempunyai hubungangan yang baik dengan para karyawan, terjalin komunikasi yang baik antara manajemen dengan para karyawan, ppemberian training kepada karyawan oleh pihak manajemen, manajemen selalu mempertimbangkan dengan para karyawan dalam pengambilan keputusan dan upaya dari manajemen untuk mensosialisasikan tentang teknologi kepada para karyawan.

b. Pihak Kantor Pajak Pratama hendaknya memprioritaskan perencanaan strategik dengan cara; penggunaan informasi yang didapat dari semua bagian untuk perencanaan strategi, sistem informasi yang baik dimiliki oleh perusahaan, karyawan mampu dalam penggunaan teknologi, perusahaan melibatkan karyawan dalam perencanaan dan dapat melaksanakan perencanaan yang sudah dibuat, karena perencanaan strategik merupakan variabel yang paling dominan pengaruhnya terhadap penerapan strategic partner.

\section{DAFTAR PUSTAKA}

Algifari, 2007. Statistik Induktjf Untuk Ekonomi dan Bisnis. UPP AMP YKPN Yogyakarta.

Sudarwan Danim, 2004, Motivasi Kepemimpinan dan Efektfltas Kelompok, PT. Rineka Cipta, Jakarta 
Gibson, Ivanchevic, Donelly, 2003, Organisasi, Perilaku_Struktur_P roses, Penerbit Erlangga, Jakarta 2003, Organisasi, Perilaku_ Struktur Proses, Bina Rupa Aksara, Jakarta

Ghozali, Imam. 2009. Aplikasi Analisis Multivariat dengan Program SPSS. Semarang: Badan Penerbit Universitas Diponegoro.

Hani T. Handoko, 2007. Manajemen Personalia dan Sumberdaya Manusia. BPFE; Yogyakarta.

Hasibuan, Drs. H. Malayu. 2006. Manajemen SDM. Jakarta: PT Bumi Aksara Jurnal Manajemen, oleh Denny, Minggu 25 November 2007.

Sugiyono dan En Wibowo, 2007, SPSS for Windows Versi 19.00. Aplikasi dalam komputer. Alfabeta, Bandung 2009, Metode Penelitian Bisnis, Alfabeta, Bandung
Siagian, Prof. Dr. Sondang. 2007. MPA: Manajemen Sumber Daya Manusia. Jakarta: PT Bumi Aksara

Sintaasih, Desak Ketut. Sudarma, dan Surachman, 2011. Knowledge ManagementdanPeran Strategic Partner SDM: Pengaruhnya Terhadap Perencanaan Strategik dan Kinerja Organisasi (Studi pada Rumah Sakit di Bali). Jurnal Manajemen Dan Kewirausahaan, Vol.13, No. 1, Maret: 18-32

Teguh, Ambar. dick. 2003. Manajemen SDM, Konsep dan Pengembangan Dalam Konteks Organisasi Publik. Yogjakarta: Graha Ilmu Yogjakarta.

Wahyudi, Drs. Bambang. 1991. Manajemen Sumber Daya Manusia. Bandung:Suta www.google.co.id

Winardi, 2002, Motivasi dan Pemotivasian Dalam Manajemen, PT. Radjagrafindo Persada, Jakarta 